\title{
Dociekania
}

\section{Centaur w zagrodzie Wenus. Machiavelli i pragnienia męskości}

Nina Gładziuk

TEKSTY DRUGIE 2020, NR 6, S. 136-156

DOI: $10.18318 /$ td.2020.6.9 | ORCID: 0000-002-9824-0453

W więzy oddaję dłonie i w niewolę idę

Owidiusz, Amores, I.2

\section{Effeminato}

Pisma Niccolo Machiavellego uchodzą za locus classicus twardej doktryny politycznego realizmu, z jej koncentracją na zdobyciu, sprawowaniu i utrzymaniu władzy, z przyświecającą jej maksymą „cel uświęca środki” oraz uznaniem sił zbrojnych za najwymowniejszy argument w obronie racji stanu. „Sztuka wojenna powinna być zapewnia autor Księcia - jedynym zatrudnieniem tego, komu przypada w udziale rozkazywanie"1. Dzierżenie władzy bez znajomości rzemiosła wojennego stanowiłoby taki sam oksymoron jak impotentna potencja. Wedle lakonicznej formuły autora: „uzbrojony nie pozostaje w żadnym stosunku do nieuzbrojonego"2. Dzieli ich różnica kategorialna, która dodatkowo nosi wyraźną

Nina Gładziuk -

doktor habilitowany, profesor Instytutu Studiów Politycznych PAN, w którym kieruje Zakładem Filozofii Polityki. Wykłada w Collegium Civitas.

1 N. Machiavelli Książę, przeł. W. Rzymowski, Zakład Narodowy im. Ossolińskich, Wrocław 1979, s. 62.

2 Tamże, s. 63. 
pieczęć rodzaju: uzbrojony reprezentuje zawsze to, co „męskie”, a nieuzbrojony - „żeńskie”.

Nie powinno nas zatem dziwić, że w wywodach Machiavellego, które utożsamiają "orężność” z maskulinizmem, najostrzejszym ze stawianych zarzutów staje się „bezorężność”, czyli bycie effeminato. Wszystkie tchórzliwe, nieskore do walki narody jawią się jako kobietopodobne. W duchu tejże logiki Florentczyk przekonuje, że pokój nie powinien być uznawany za ostateczny dobrostan państwa, bo „jeśli łaskawe niebiosa oszczędzą mu wojny, pokój doprowadzi je do zniewieściałości”3. Snując zaś rozważania nad momentem założycielskim Rzymu, za szczęśliwy obrót Fortuny uznaje fakt, że po pokojowo usposobionym Numie nastali królowie, którzy kontynuowali „wojenne męstwo” Romulusa - „inaczej bowiem miasto zniewieściałoby i padłoby ofiarą sąsiadów"4.

Kategoria effeminato pojawia się wszędzie tam, gdzie mamy do czynienia z sytuacją, w której nie trzeba walczyć. Toteż w zniewieściałość popadają władcy, którzy o tron bić się nie muszą, bo ten należy im się zgodnie z prawem dziedziczenia. Pewność otrzymanej w ten sposób władzy nie wymaga dzielności i dlatego czyni ich słabeuszami. Wszyscy książęta, którzy nie znają się na wojowaniu, podobni są do „niezdolnego do walki tłumu starców, kobiet i dzieci", o jakim przy okazji wojen galijskich czytamy w Rozważaniach nad pierwszym dziesięcioksiegiem historii Rzymu Liwiusza ${ }^{5}$.

Kompetencja władcza ulega szybkiej erozji, gdy nie towarzyszy jej potencjał militarny, ale kardynalnym błędem każdego panującego jest opieranie się na wojskach zaciężnych. Zniewieściałość polega tu na poniżającym uzależnieniu od obcych najemników, co skutkuje pozorowanymi, w istocie defetystycznymi operacjami militarnymi: „Kiedy ci tchórzliwi władcy lub te zniewieściałe republiki wysyłają na wojnę wodzów swoich armii, udzielają im najmądrzejszego w swym mniemaniu zlecenia, a mianowicie żeby starannie unikali bitwy i za żadną cenę nie dopuszczali do walki wręcz"6. Feminizację danego ludu spowodować też może przywyknięcie do rządów zaborczych: „Tebańczycy Pelopidas i Epamonidas, po wyzwoleniu swej ojczyzny

3 Tamże, s. 257.

4 N. Machiavelli Rozważania nad pierwszym dziesięcioksięgiem historii Rzymu Liwiusza, w: tegoż Wybór pism, przekład zbiorowy, Państwowy Instytut Wydawniczy, Warszawa 1972, s. 295.

5 Tamże, s. 481.

6 Tamże, s. 537. 
i zrzuceniu z niej spartańskiego jarzma, znaleźli się w mieście nawykłym do niewoli, wśród zniewieściałego ludu"7. Sparta, sławiona przez Machiavellego z racji dwóch mężnych kompetencji - sztuki wojennej i republikańskiego samorządu - jako hegemon celowo ukobieca podległe sobie kraje, rozbrajając je i narzucając im jarzmo niewoli.

Wielka jest rola kultów religijnych w sprawianiu, że jedne ludy stają się męskie, czyli orężne, inne zaś żeńskie, czyli bezorężne. Religia starożytnych sprzyjała kultywowaniu tego, co bohaterskie, nakazywała bowiem „oddawać cześć boską ludziom, którzy okryli się sławą doczesną, jak dowódcom wojskowym i naczelnikom państwa" ${ }^{\text {. W }}$ ten sposób dodawała ona wigoru życiu publicznemu. Inaczej rzecz ma się z chrześcijaństwem, które przez swój kontemplacyjny, pozaświatowy i pacyfistyczny charakter wpaja pogardę dla polityki i militariów. Potępiając dążenie do wielkości i sławy, w zamian zaś propagując bierną pokorę, chrześcijaństwo odpowiedzialne jest za stopniowe zanikanie animuszu: „Z tych to powodów zakorzeniła się w świecie słabość, wydając ten świat na łup niegodziwców, którzy bezpiecznie nim władają, bo wiedzą, że ludzie w trosce o dostąpienie raju skłonni są bardziej do znoszenia krzywd niż do ich pomszczenia".

Jak widzimy, bycie effeminato obejmuje całe spektrum różnorakich postaw: od słabości i tchórzostwa, wydelikacenia i skupienia na wygodach, zgody na niewolę, służalczości i uzależnienia od innych przez awersję do wysiłku i podejmowania ryzyka aż po brak ambicji i dążenia do wiekopomnej sławy. Zniewieściałość, naczelna przywara w kodeksie etycznym Machiavellego, dotknąć może nieomalże wszystkiego: wychowania i sposobu życia, temperamentu narodowego, ustroju politycznego i stylu sprawowanej władzy, strategii wojennej i organizacji sił zbrojnych, religii, a nawet ducha czasów.

Najbardziej pożądane w myśli Machiavellego wartości, takie jak samodzielność i niezależność albo autonomia i autarkia, są trwale splecione z rodzajem męskim. Jednak ten ostatni pozostaje w niestałym związku z płcią. Przywara zniewieściałości, wbrew swej etymologii wcale nie będąc immanentną cechą kobiet, trapi męskie instytucje i męskie praktyki. Ani tron, ani plac publiczny, ani pole bitwy nie są od popadnięcia w nią wolne.

\footnotetext{
7 Tamże, s. 299.

8 Tamże, s. 394.

9 Tamże.
} 
Wydawałoby się, że polityczną antropologię Machiavellego z łatwością odczytywać można jako przypadek militarnego maskulinizmu. A jednak jego rozproszony we wszystkich dziełach dyskurs o męskiej płci i rodzaju jest dużo bardziej skomplikowany. Rodzaj męski nie jest czymś z natury danym, ale zadanym. Osiągnąć go można w warunkach nieustającego alertu, czujności, by nie popaść w proces niewieścienia. Rozważaniom autora stale towarzyszy też kobieca figura ponadludzkiej mocy - Natury, Konieczności, Fortuny czy Wenus. Orężna na rozmaite sposoby rzuca wyzwanie projektowi męskiej autonomii i męskiej autarkii.

\section{Przemiany}

W całej twórczości Machiavellego, zarówno w pismach poświęconych historii politycznej i militarnej, jak i w utworach lżejszego kalibru, takich jak komedie czy poematy, znajdujemy to samo uporczywe odwoływanie się do rodzaju męskiego jako stałej sensotwórczej normy. Jednak specyficzne imaginarium, w ramach którego porusza się myśl autora, kwestionuje jakąkolwiek stałość. Lektury Owidiusza, a także na nowo odkrytego Lukrecjusza wzbudzają wśród renesansowych twórców we Włoszech fascynację ideą ciągle przeobrażających się form istnienia. W Metamorfozach rzymskiego elegisty czytamy: „Nic nie zachowuje swojego wyglądu: Natura, wielka odnowicielka, wciąż zmienia jedne formy w inne"10. Dominującemu w średniowieczu pojmowaniu natury jako statycznej hierarchii bytów wyobraźnia renesansowa przeciwstawia obraz ich zmiennej polimorficzności, czego świadectwem są najważniejsze nurty myślowe epoki.

Dzieła Owidiusza i Lukrecjusza, uważnie przez Machiavellego studiowane, wyostrzały jego percepcję świata jako nieustannego kołowrotu przemian i wiodły do przekonania o płynności wszelkich dystynkcji. To dlatego podjętą przez autora rewindykację masculinum jako trwałej normy człowieczeństwa uznać należy za projekt paradoksalny. Jak bowiem w ramach światopoglądu, który wszędzie dostrzega ruch i metamorfozę, dać wiarę temu, że rodzaj męski jest niezmienny?

Ciekawym w tym kontekście przypadkiem jest Platońska próba połączenia porządku hierarchicznego z dynamiką przemian. W Timajosie znajdujemy pojęcie „złotego sznura” wznoszącego się ku górze od materii nieożywionej

10 Owidiusz Metamorfozy, przeł. A. Kamieńska i S. Stabryła, Zakład Narodowy im. Ossolińskich,Wrocław 1995, s. 419. 
poprzez świat zwierzęcy i ludzki. Na owej łączącej ziemię z niebem drabinie istnienia to, co męskie, sytuuje się na samym jej szczycie, to, co zwierzęce, u jej dołu, to zaś, co żeńskie, pomiędzy męskim a bestialnym. Hierarchia bytów nie jest tu statyczna, ale poddana podobnemu jak $u$ Owidiusza ruchowi przemian: „wszystkie jestestwa żywe przemieniają się jedne w drugie, przechodząc z jednego gatunku do drugiego"11. Gatunkiem pierwotnym, usytuowanym najbliżej bogów, jest mężczyzna jako istota rozumna i odważna. Ale i on nie jest immunizowany na przemianę. Gdy popadnie w bezrozumność - przeistoczy się w zwierzę: „Zwierzęta lądowe i dzikie zrodziły się z ludzi, którzy nie posługują się filozofią" ${ }^{\prime 2}$. Gdy ulegnie tchórzostwu - przeistoczy się w kobietę: „Wszyscy mężczyźni, którzy byli tchórzliwi i żyli niegodziwie, w swoim drugim życiu zmienili się, zgodnie z prawdopodobieństwem, w kobiety"13. Pomimo ontologicznie uprzywilejowanej pozycji mężczyzna zawsze może zsunąć się w dół skali bytów i ulec odpowiednio skobieceniu albo bestializacji. Jednak znakiem jego ostatecznej degradacji jest zezwierzęcenie i poruszanie się na czworaka: „Bóg dał głupszym liczniejsze podpory, ponieważ byli silniej przyciągani ku ziemi"14.

Platońska androgonia stwarza ciekawy kontrapunkt dla koncepcji masculinum pojawiającej się w utworach Machiavellego. U obu myślicieli człowieczeństwo tożsame jest z rodzajem męskim, choć ten nie przysługuje płci męskiej w sposób trwały i łatwo można go utracić. U Platona jednak męskość rozumiana jest przez związek z tym, co „u góry” - rozumem, niebem i tym, co boskie - u Machiavellego natomiast przez związek z tym, co „u dołu” - ziemią, naturalnymi instynktami i tym, co zwierzęce. Podczas gdy zniewieściałość spotyka się u niego zawsze z potępieniem, bestialność staje się przedmiotem apologii:

Dlatego też książę musi doskonale umieć używać zarówno natury zwierzęcej, jak i ludzkiej. Ta nauka podana jest książętom w napomknieniach już przez pisarzy starożytnych, którzy opowiadają jak Achilles i wielu innych królów greckich oddani byli na wychowanie do Chirona centaura, pod opieką tegoż wzrastali; to odbywanie szkoły pod kierunkiem

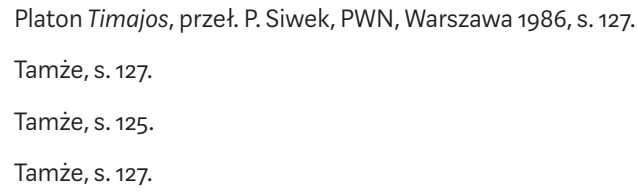


pół bestii, pół człowieka, nie oznacza nic innego, tylko wskazówkę, że powinnością księcia bywa używanie tak jednej, jak drugiej natury, jedna bez drugiej ostać się nie może. ${ }^{15}$

\section{Centaur}

Koncepcję męskości, która - za sprawą nośnej figury centaura - wyłania się $\mathrm{z}$ różnorakich utworów Machiavellego, można by nazwać centaurialną. Stanie się ona wyraźniejsza, gdy skontrastujemy ją z andrologicznymi pomysłami Cycerona i Platona. Zacznijmy od Cycerona, u którego znajdujemy słynne utożsamienie męskości z cnotą:

Cnota, bowiem, po łacinie virtus, nazywa się tak od męża, vir, dla męża zaś najbardziej właściwe jest męstwo, które ma dwie główne powinności: pogardę śmierci oraz bólu. Trzeba więc spełniać te powinności, jeśli chcemy mieć udział w cnocie, czy raczej być mężami, skoro nazwa "cnota" (virtus) jest urobiona od nazwy "mąż” (vir). ${ }^{16}$

Męska dusza, składająca się z części niższych i wyższych, przypomina uwewnętrzniony obóz wojenny. Dowódcą i rozkazodawcą jest tutaj rozum, podkomendnymi zaś wszystkie "miękkie” części duszy. Męskie Ja to relacja między instancją rozkazu a obowiązkiem subordynacji, gdzie porządek militarny pokrywa się z patriarchalnym: „Bądź tak, jak pan niewolnikowi, bądź jak wódz żołnierzowi, bądź jak ojciec synowi"17. Czasami wewnętrzna instancja rozumnego rozkazu nie wystarcza i wówczas nieodzowna staje się zewnętrzna presja wywierana przez męskie otoczenie. Dlatego Arpinata radzi:

Jeżeli ta część duszy, o której powiedziałem, że jest miękka, sprawuje się haniebnie, jeżeli jak kobieta oddaje się lamentom i łzom, to niech ją skrępuje i powściągnie dozór przyjaciół i krewnych; nieraz bowiem widzimy, że ludzie, którzy nie ulegli rozumowi, pohamowali się ze wstydu. ${ }^{18}$ Cyceron Rozmowy tuskulańskie, w: tegoż Pisma filozoficzne, t. 3, przeł. J. Śmigaj, PWN, Warszawa 1961, s. 573. Tamże, s. 576. Tamże, s. 576-577. 
Męskość polega nie tylko na pokonaniu w sobie tego, co kobiece, ale i na stłumieniu tego, co bestialne: „Bo jakaż to różnica, czy ktoś z człowieka przemieni się w zwierzę, czy też w postaci ludzkiej będzie żywił zwierzęcą dzikość?" „zwierzęcej dzikości”, w Cycerońskiej koncepcji masculinum nie ma miejsca na seksualność. Inaczej jest u Platona. On również „szał weneryczny” wiąże z tym, co w mężczyźnie animalne, ponieważ owładnięty nim „okrakiem”20 pcha się na obiekt swego pożądania i bierze go w posiadanie niczym „czworonożne zwierzę"21. W Fajdrosie pojawia się metafora woźnicy powożącego zaprzęgiem dwóch koni, z których jeden symbolizuje żądzę nieokiełznaną, drugi zaś żądzę trzymaną na wodzy. Przemożność tej pierwszej jest tak wielka, że „nie zważa na ukłucia ani razy, których woźnica nie szczędzi, i w dzikich podskokach pędzi wprost przed siebie"22. Ostatecznie woźnica odzyskuje kontrolę nad całym zaprzęgiem, co obrazować ma zdobytą przez mężczyznę zdolność panowania nad tym, co w nim bestialne. Jednak rozumna męska podmiotowość nie mogłaby się ukonstytuować bez zmagań z dzikością żądzy seksualnej. Platońską metaforykę kontynuuje Dante w Biesiadzie, gdzie pożądliwość niepoddana cuglom rozumu przyrównana jest do „puszczonego wolno wierzchowca"23. W ramach tej hippicznej poetyki relacja między rozumem a apetytem (czyli żądzą) polega na „ściganiu i umykaniu”, na ujeżdżaniu pożądania za pomocą "cugli i ostróg”24. Męska cnota może być zatem wyobrażona jako jeździecka sprawność:

Cugli używa, gdy tamten coś ściga, i nazywają się te cugle wstrzemięźliwością, i ona wskazuje granicę, do której ścigać należy. Ostróg używa, gdy on umyka, by zawrócić do miejsca, z którego umknąć pragnie. I ostrogi te zwane są Męstwem lub też Wielkodusznością, i ta cnota wskazuje miejsce, gdzie należy się zatrzymać i stanąć do walki. ${ }^{25}$

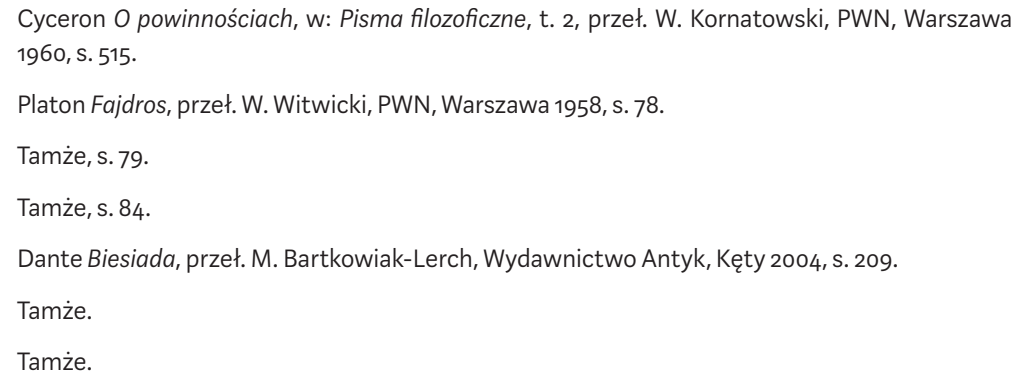


Również u Dantego to, co seksualne, okazuje się konieczne do uformowania się wewnętrznych „cugli i ostróg”, zdolności powściągania, hamowania i zawracania.

Machiavelli, w odróżnieniu od Cycerona i Platona, kwaterę główną męskości przenosi z rozumu do tymotejskiej sfery piersi i sąsiadującej z nią zwierzęcej sfery podbrzusza. Wierny maksymie, że „wszystkie czyny nasze są naśladownictwem przyrody", nobilituje męską seksualnośćc ${ }^{26}$. Przestaje ona być tym, co należy stłumić albo trzymać w ryzach, a staje się źródłem libidalnej energii nieodzownej we wszelkim dążeniu do władzy. Samczość u autora Księcia stanowi nie tylko, jak u Platona, warunek konstytuowania się męskiego podmiotu, ale jego trwały trzon. Związek między samczością a męską cnotą - u Cycerona całkiem zerwany, u Platona częściowo zachowany - u Machiavellego tworzy mocny i nierozwiązywalny supeł. Machiavelli odrzuca utożsamienie męskości z tym, co rozumne, duchowe i etyczne. Miejsce tych władz zajmują seksualna potencja, duch bojowy i wola panowania. Nie przypadkiem zatem, aby zobrazować zmagania męstwa z losem, autor Księcia sięga po metaforę seksualnego podboju kobiety: „lepiej być nadto obcesowym niż nadto oględnym, gdyż Fortuna jest kobietą i odtrąca tych, którzy nie bywają zuchwali, dlatego też, jak kobieta, ulega najczęściej młodym, którzy nie grzeszą oględnością, lecz rozkazują jej butnie i śmiało"27. Wyjaśnia to dlaczego virtù Machiavellego, w odróżnieniu od Cycerońskiej virtus, rzadko tłumaczona jest jako „cnota”, zazwyczaj zaś jako - moralnie indyferentny talent, wirtuozostwo, dzielność czy animusz. Zapanować nad losem udaje się nie dzięki rozumowi i cnocie etycznej - przekonuje autor Księcia - ale dzięki sile, egzekucyjnemu geniuszowi i werwie. Fortuna bowiem nie mądrym sprzyja, ale odważnym.

Rozproszone rozważania Machiavellego nad masculinum łączy postać centaura. Ewokuje ona zestrój cech, które od czasów grecko-rzymskiego antyku symbolicznie przypisywane są koniom. Najbardziej znana jest asocjacja konia z ityfallicznym pobudzeniem. Do niej właśnie nawiązuje hippiczna metaforyka, którą Platon i Dante posługują się w opisie popędu seksualnego. Dla pierwszego żądza jest jak przemożny mus pokrycia, który sprawia, że ogier stara się „wskoczyć przednimi nogami na kochanka"28, dla drugiego jest ona

\footnotetext{
26 N. Machiavelli Rozważania..., s. 398.

27 N. Machiavelli Książę, s. 111.

28 Platon Fajdros, s. 84.
} 
jak „puszczony wolno wierzchowiec"29. Jednak symboliczne uniwersum konia każe zwierzę to wiązać nie tylko z Wenus, ale i z Marsem. W wersach Wergiliusza na temat „płomiennego szału”, jaki za sprawą Wenus ogarnia ludzi i dzikie zwierzęta, pojawia się figura konia: „Alboż nie widzisz, jak drżenie ogarnia ciało ogiera, / Kiedy do nozdrzy mu znana doleci woń przez powietrze?" ${ }^{\prime 30}$. Nieco wcześniej w poemacie znajdujemy opis ogiera, gotowego do ataku bojowego: „Taki ogier, gdy tylko usłyszy szczękanie oręża, / Ustać nie może, strzyże uszami i wstrząsa się cały, / Parska i dymi z nozdrzy rozdętych, ogniem błyskając"31. Opisy drżenia i wstrząsania, które - czy to za sprawą Wenus, czy to za sprawą Marsa - przechodzą ciało zwierzęcia, okazują się dziwnie podobne.

Tym, co nas w tym miejscu zajmuje, jest szczególny związek potencji seksualnej z potencją bojową. W kulturze greckiej związek ten reprezentuje właśnie centaur uosabiający męskie siły w przyrodzie.W tym anthropos therion, ludzko-końskiej hybrydzie, samczość ludzka i zwierzęca zostają spotęgowane. Jako stworzenia ogieropodobne centaury równie namiętnie popadają w szał Erosa, co w szał bojowy. Odrzuciwszy małżeństwo, rodzinę i życie domowe, przenoszą nad nie dziką egzystencję w lasach, w warunkach jednopłciowej, samczej wspólnoty. Z tego powodu grecki mit przedstawia je jako główne zagrożenie dla zasad patriarchalnego ładu, czemu daje wyraz słynna centauromachia. Do brutalnej walki między mężczyznami a centaurami doszło - jak głosi opowieść - na weselu króla Lapitów. Zarzewiem konfliktu była podjęta przez centaury próba porwania kobiet obecnych na uczcie. Walka centaurów z Lapitami stanie się popularnym tematem w sztuce włoskiego renesansu, a najbardziej znanymi jego przedstawieniami są przejmujący obraz Pierra di Cosimy oraz marmurowa płaskorzeźba Michała Anioła. W politycznej mitologii Rzymu przykładem hipermęskiego splotu jurności i waleczności jest postać Romulusa. Ojciec założyciel Wiecznego Miasta, którego geniusz Machiavelli sławi na licznych kartach swych dzieł, nosi wyraźne cechy centaurialne. Wykarmiony przez wilczycę heros nigdy nie pozostawał głuchy na głos natury. Potęgę Rzymu budował wojnami, najazdami i zaborem cudzych ziem. Obok talentu bojowego wykazał się też porwaniem Sabinek. Zaradziło to deficytowi kobiet w początkach państwa, na którego populację składała się - na podobieństwo centaurów - homospołeczna wspólnota rozbójniczych żołnierzy.

Dante Biesiada, s. 209.

Wergiliusz Georgiki, w: tegoż Bukoliki i georgiki, przeł. Z. Abramowiczówna, Zakład im. Ossolińskich, Wrocław 1953, s. 93.

Tamże, s. 91. 
W bliższych sobie czasach figurę zdobywczego centaura wiąże Machiavelli z „nowym księciem”, którego ucieleśnieniem jest kondotier, militarno-polityczny wirtuoz. Ktoś taki jak podziwiani przez autora - Francesco Sforza, Cesare Borgia, Fabrizio Colonna czy działający wiek wcześniej Castruccio Castracani. Wedle Jacoba Burckhardta "condottiere, który bez względu na swe pochodzenie zdobywa sobie udzielne księstwo", reprezentuje w epoce włoskiego renesansu najbardziej awanturniczy, a zarazem genialny typ męskiej persony ${ }^{32}$. Niedający się spacyfikować przez nakazy religii, patriarchalne obowiązki czy wymogi obyczajności kondotier jawi się jako prefiguracja Nietzscheańskiej „bestii”. W ustawicznym dążeniu do władzy

niejeden [...] żywi najgłębszą pogardę dla wszelkiej świętości, posługuje się okrucieństwem i zdradą, a prawie wszyscy umierają obojętni na ciążącą nad nimi klątwę kościelną. Równocześnie jednak rozwijają się u niejednego indywidualności i zdolności, osiągające najwyższy szczyt wirtuozostwa $[\ldots] .^{33}$

Słowo "wirtuozostwo" trafnie oddaje sens virtù jako talentu egzekucyjnego, sprawnego wprowadzania ryzykownego zamiaru w czyn czy błyskawicznego pochwytywania nadarzającej się okazji. Okazja, Occasione, przedstawiana jako młoda dziewczyna, to jedna z wielu personifikacji Fortuny. Jej złapanie, pochwycenie czy porwanie odsyła do toposu raptus puellae, siłą wziętej czy uprowadzonej branki. W tym kontekście intrygująca jest uwaga Burckhardta, że „we Włoszech zwyczaj głośnego chełpienia się względami fortuny wprowadzili prawdopodobnie kondotierzy"34. Czyżby zwyczaj ten inspirował znaną nam już metaforę seksualnego ujarzmienia Fortuny? W każdym razie stosunek księcia czy kondotiera do Fortuny żywo przypomina stosunek centaurów do kobiet lapickich czy Romulusowych żołnierzy do Sabinek.

Ponieważ „nowi książęta” stanowią u Machiavellego przykłady propagowanej przezeń centaurialnej koncepcji męskości, przyjrzyjmy się jednemu z nich. W Żywocie Castruccia Castracaniego, kondotiera i tyrana Lukki, znajdujemy wiele kluczowych dla tej koncepcji momentów. I tak jako chłopiec Castruccio porzuca to, co u Machiavellego zawsze traktowane jest jako

$32 \mathrm{~J}$. Warszawa 1965, s. 14. 
niemęskie, mianowicie „studiowanie ksiąg”, na rzecz tego, co męskie, czyli "nauki posługiwania się bronią"35. Rychło zdobywa laury sprawnościowego mistrza: „w każdej akcji, gdzie była potrzebna siła lub zręczność, nie znajdował się nikt, kto by mógł go przewyższyć"36. Wszystkim jego poczynaniom, wolnym od jakichkolwiek obaw, towarzyszy nadzwyczajna brawura: „Nikt nigdy nie rzucał się z większą odwagą w wir niebezpieczeństw ani też lepiej umiał się z nich wydostać; zwykł też powtarzać, że ludzie powinni być zdolni do wszystkiego i nic ich nie powinno lękać i że Bóg kocha ludzi silnych, ponieważ, jak to się widzi wszędzie, karze słabych rękami silnych"37. Męski wigor łączy się w bohaterze z niechęcią do hymenalnych zobowiązań, toteż nie szczędzi on pochwał tym, którzy „nigdy nie wstępują w związki małżeńskie" ${ }^{38}$. Gdy zarzucono mu, że w sprawach Amora "postępuje źle, skoro dał się pogrążyć kobiecie”, miał odpowiedzieć za pomocą takiej oto riposty: „nie ona mnie pogrążyła, tylko ja się w niej pogrążyłem" ${ }^{\prime 39}$. Wedle tej sugestywnej frazy, jaką Machiavelli wkłada w usta tyrana Lukki, penetracja nadaje męskiemu ciału władczy charakter, bo bierze ono w posiadanie inne. Jako manifestacja libido dominandi męska seksualność stanowi zatem sensualną podstawę męskiej dyspozycji do władzy. Toteż androcentryczna w utworach Florentczyka koncepcja virtù czasami jawi się jako wręcz androseksualna. W czwartym rozdziale poematu Złoty osioł pomiędzy rozmaitymi jej znaczeniowymi odcieniami znajdujemy także najdosłowniejszy stan erekcji ${ }^{40}$.

Popularnym refleksem andrologii Platona i Cycerona w literaturze wczesnorenesansowej jest Bokacjuszowy Labirynt miłości albo skrzeczacy kruk, w którym narrator, sfrustrowany kobiecą żądzą panowania, zapewnia: „jesteśmy wyżsi od kobiet i zwierząt"41. Uporczywie powraca tam motyw mężczyzny jako korony bytów: „Obok aniołów jest [...] mężczyzna najdoskonalszym

\footnotetext{
35 N. Machiavelli Żywot Castruccia Castracaniego z Lukki, w: tegoż, Wybór pism, s. 671.

36 Tamże, s. 673.

37 Tamże, s. 696.

38 Tamże, s. 699.

39 Tamże, s. 697.

40 Por. N. Machiavelli The [Golden] Ass, w: tegoż The Chief Works and Others, vol. 2, transl. A. Gilbert, Duke University Press, Durham 1989.

41 G. Boccaccio Labirynt miłości albo skrzeczacy kruk, przeł. E. Boye, Biblioteka Romansów i Powieści, Warszawa 1930, s. 92.
} 
tworem Boga"42. Dla Machiavellego, orędownika głosu natury i odzyskanych instynktów, jeżeli mężczyzna miałby przypominać anioła, to z pewnością byłby to anioł „wcielony”, jak angelo incarnato na słynnym rysunku Leonarda da Vinci - anioł ze wzwiedzionym fallusem.

\section{Zwierzyniec Kirke}

W pobudzeniu tego, co w mężczyźnie bestialne, dostrzegał Machiavelli szansę na rewalidację maskulinizmu. W kulturze renesansowej znajdujemy również odmienny trop, zgodnie z którym teriantropia mężczyzny prowadzi do jego demaskulinizacji. Kluczową rolę odgrywa tu kobieca moc weneryczna, która unicestwiwszy to, co w mężczyźnie podmiotowe, sprowadza go do niższych funkcji animalnych, wiedzie ku mrocznym czeluściom natury, w których buzuje voluptas veneria.

Wedle Homerowej Odysei dwudziestu śmiałków wyprawiło się na tajemniczą wyspę, gdzie napotkali mnóstwo zwierząt. Choć drapieżne z wyglądu, zachowywały się osobliwie potulnie: „Nie rzuciły się, owszem, kornie się im łaszą" ${ }^{\text {*3 }}$. Królową wyspy, której pałac stał pośród ciemnego lasu, okazała się Kirke. Za pomocą czarów wabiła do siebie mężczyzn, by następnie przeobrażać ich w różne zwierzęta. Taki los miał też spotkać towarzyszy Odyseusza przemienionych w świnie i zapędzonych do zagrody: „Więc gdy zjedli, wypili, Kirka ich dotyka / Różdżką i do świńskiego zapędza karmnika. / Bowiem łby ich, szczecina, kwiczenie, kształt cały / Były świńskie, li człecze mózgi im zostały”44. Topos Kirke, z upodobaniem przywoływany w literaturze i sztuce renesansu, unaocznia związek erotyki ze zmienną relacją dominacji i podporządkowania. Oto silni i waleczni mężczyźni, znalazłszy się w obszarze voluptas veneria, ulegają zezwierzęceniu, które jednak nie wzmacnia ich samczości, ale raczej ją kastruje. Kreśląc przed Odyseuszem obraz Kirke jako mizandrycznej dominy, Euryloch powiada: „Ona nie oszczędzi / Żadnego, wszystkich zamieni w lwy, wilki i wieprze, / Przemienionych wraz zmusi służyć jej w najlepsze" ${ }^{\text {"45 }}$. Utraciwszy samczą drapieżność, mężczyźni przeobrażają się w łagodne, oswojone zwierzęta, żyjące odtąd na łasce i niełasce swej pani.

\footnotetext{
42 Tamże 
Topos Kirke wykorzystuje Boccaccio w opowiastce Labirynt miłości albo skrzeczacy kruk. Apetyt Wenery, pożądanie rozkoszy cielesnej, wabi mężczyzn w ustronne królestwo bez wyjścia, gdzie zostają przemienieni w bezrozumne zwierzęta: „Ta zła dolina jest zagrodą miłości zmysłowej, a zwierzęta, których ryki słyszysz, to owi nieszczęśliwi, schwytani w sidła fałszywej i złej namiętności" ${ }^{46}$. Zamknięty obszar kobiecej mocy powodującej teriantropię mężczyzn nosi rozmaite nazwy: „Jedni zwą go labiryntem miłości, drudzy zaczarowaną doliną lub chlewem Wenery" ${ }^{\text {"77 }}$. Tym, co przyciąga naszą uwagę w tej antyfeministycznej diatrybie, jest wątek transgresji rodzaju żeńskiego, której dopuszczają się podobne do Kirke kobiety. Powoduje nimi żądza dominacji nad mężczyzną: „Stworzone do posłuszeństwa, starają się schwycić wszelką władzę w swe ręce" ${ }^{\text {"48 }}$. Czynią to podstępem, aby ten, który padł ofiarą, nie zauważył, że „wszystko jest orężem, służącym do pokonania jego hartu i władzy"49. Za nic mając patriarchalną zwierzchność swoich mężów, dają upust przewrotnemu pragnieniu „bycia na wierzchu”"50. Skupione tylko na tym, by „wolność mężczyzn schwytać w pułapkę”, odwracają hierarchię rodzaju i zamiast być trofeum, same stają się łowczyniami mężczyzn ${ }^{51}$.

Figura dominatrix przeobrażającej mężczyznę w uległe jej rozkazom zwierzę była często wykorzystywana w ikonografii odrodzenia. Poza Kirke czy Wenus warta przywołania jest tu postać Fylis, której motyw zdobił nie tylko świeckie przedmioty użytkowe, ale pojawiał się nawet w dekoracjach kościołów. Według popularnej w renesansie legendy Arystoteles, nauczyciel Aleksandra Wielkiego, wyrzucał swemu pryncypałowi, że ten za dużo czasu poświęca Fylis ze szkodą dla tego, co męskie - filozofii i spraw państwowych. Rozgniewało to niewiastę, która postanowiła, że uwiedzie i upokorzy mędrca. Przyszło jej to bez trudu. Omamiony perspektywą dzielenia z nią łoża Arystoteles stracił głowę. Bez wahania spełnił jej rozkaz: zszedł na czworaka i na własnym grzbiecie zaczął wozić swoją panią. Wizerunek dominy ujeżdżającej mężczyznę stanowił skandaliczną ilustrację świata na opak, w którym kobieta wywraca kulturowo usankcjonowaną pozycję męskiej

46 G. Boccaccio Labirynt miłości..., s. 55.

47 Tamże, s. 47.

48 Tamże, s. 75.

49 Tamże.

50 Tamże, s. 78.

51 Tamże, s. 75. 
podmiotowości i męskiej władzy. Na ironię zakrawa, że wierzchowcem dla Fylis stał się Filozof, przez stulecia czczony autor mizoginicznej teorii kobiety jako „wybrakowanego mężczyzny”.

Wokół motywu bestiarium Kirke osnuty jest też niedokończony poemat Machiavellego Złoty osioł. Utwór, w którym nietrudno zauważyć wpływy Owidiusza i Apulejusza, opowiada o mężczyźnie, który nie wiedzieć czemu, „utraciwszy całą swą wolność", znajduje się nagle pośrodku surowego krajobrazuª̨ Wypełniający go ciemny las stanowi sferę liminalną, oddzielającą królestwo Kirke od reszty świata. Porzuciwszy ludzką społeczność i jej prawa, Kirke obrała na swą siedzibę dzikie pustkowie, gdzie żyje „wroga mężczyznom”, a pod wodzą ma wyłącznie kobiety ${ }^{53}$. Każdemu śmiałkowi, który pojawia się w matriarchalnym państwie Kirke, grozi śmierć albo przemienienie w zwierzę. Sądząc po mnogości różnorakich zwierząt, wielu nieroztropnie to uczyniło. Po tym, jak uszy przybysza przeszywa przejmujący dźwięk rogu, z lasu wyłania się młoda, rosła i piękna kobieta z latarnią w lewej ręce i rogiem w prawej. To pasterka w imieniu Kirke zarządzająca stadem zwierząt. Właśnie prowadzi swych podopiecznych z dziennego popasu na nocny spoczynek w zagrodzie. Rychło po zawarciu znajomości z bohaterem radzi mu, by „zszedł na czworaka" i wmieszał się w stado, bo inaczej Kirke rozpozna jego ludzkie oblicze ${ }^{54}$. Ten, posłusznie idąc za radą swej protektorki, deklaruje całkowite poddanie sięjej władzy. Zważywszy na amazoński porządek panujący w państwie Kirke, sympatia, jaką pasterka żywi wobec przybysza, jest wyraźnie subwersywna i czyni z niej postać dysydencką. Wyglądem i leśnymi zamiłowaniami przypominająca Dianę, w odróżnieniu od niej nie pozostaje intacta. Na odwrót, prowadzi zbłąkanego do swej siedziby, raczy ucztą i zaprasza do łoża. Ów, ległszy obok ponętnej, ale ze wszech miar dominującej mentorki, truchleje, po czym doświadcza impotencji. Pragnąc oddać demaskulinizujący efekt, jaki wywołuje kobieca przewaga, Machiavelli odwraca rodzaj bohatera i porównuje go do znieruchomiałej panny młodej, szczelnie owiniętej pościelą i pełnej obaw przed defloracją ${ }^{55}$. Kochanków łączy jednak nie tylko eros, ale i logos. W przerwach między niedyspozycją mężczyzny a odzyskanym przez niego wigorem toczą ze sobą długie dysputy.

\footnotetext{
52 N. Machiavelli The [Golden] Ass, s. 753.

53 Tamże, s. 755.

54 Tamże, s. 756. 
Utwór zawiera wiele intrygujących wątków: dantejską wędrówkę zbłąkanej duszy przez rozmaite stany, historiozoficzną medytację nad powstaniem i upadkiem imperiów, opowieść miłosną, amazońską wojnę płci, zagrażającą mężczyznom perspektywę teriantropii, rozważania na temat różnic oddzielających świat ludzki od zwierzęcego. W końcowej części poematu słyszymy tyradę wieprzka na temat owych różnic. Jedną z nich jest „apetyt Wenery”, czyli popęd seksualny. Autor tyrady, który stanowczo przenosi swe beztroskie taplanie się w błocie nad ludzką egzystencję rozdzieraną przez sprzeczności, rezonuje: „Sprawom Wenus poświęcamy czasu niewiele i czynimy to krótko. A Wy [ludzie] dążycie do nich bez umiaru, w każdej chwili i w każdym miej$\mathrm{scu}^{\text {"56. }}$. Apetyt Wenery błędnie uważany jest za to - przekonuje mówca - co w człowieku zwierzęce, w istocie bowiem jest to przypadłość czysto ludzka. I taki też wydaje się ogólny morał poematu: nienasycalność pożądania seksualnego podobna jest do nienasycalności ambicji politycznej i dlatego obie żądze dostarczają libidalnego podłoża dla nieustającej zmienności ludzkich spraw.

Jak widzimy, oba toposy - centaura z jednej, zwierzyńca zaś Kirke z drugiej strony - wskazują na dwuznaczność tego, co bestialne, w konstrukcji masculinum. Jeden rodzaj bestialności, symbolizowany przez centaura, miał męskość wzmacniać i chronić przed zniewieścieniem, drugi, odsyłający do bestiarium Kirke czy zagrody Wenus, obnażał impotencję męskości pozostającej „na czworaka" pod kobiecą władzą seksualną.

\section{W zagrodzie Wenus}

Narodziny Wenus, obraz Sandra Botticellego, z wielu powodów stanowią dzieło przełomowe we włoskim renesansie. Po raz pierwszy w chrześcijańskiej kulturze przedstawiona została naga pogańska bogini. Zważywszy monumentalne rozmiary płótna, obraz sprawia wrażenie ołtarza zmysłowego piękna i przywodzi na myśl wersy z pierwszej księgi poematu Lukrecjusza, gdzie przyznawszy „Wenus matczynej” majestat najważniejszego rzymskiego bóstwa, poeta inkantuje: „od ciebie jedynej zależy natura rzeczy”' ${ }^{57}$. Dzieło Botticellego daje wyraz rozbudzonej pasji, z jaką studiuje się naturę i miłość, a zwornikiem tych zainteresowań jest właśnie figura Wenus. Jako Wenus

\footnotetext{
56 Tamże, s. 771.

57 Lukrecjusz O naturze rzeczy, przeł. G. Żurek, Państwowy Instytut Wydawniczy, Warszawa 1994, s. 53 .
} 
niebiańska, czy uraniczna, staje się ona ośrodkiem neoplatońskich rozważań nad rolą zmysłowego piękna w dążeniu do ponadzmysłowego świata duchowości. Jako Wenus pospolita, bogini miłości zmysłowej, patronuje nowelom Boccaccia i dialogom Aretina.

Bogata w kulturze renesansowej ikonografia romansu Wenus i Marsa dawała wyraz przeświadczeniu, że miłość wiele ma wspólnego z wojną.Źródłem inspiracji okazała się tu rzymska elegia miłosna z dziełami Owidiusza na czele. Zarówno jego wczesne Amores, jak i późniejsza Ars amatoria dostarczyły wielu retorycznych tropów, które silnie wpłynęły na imaginację pisarzy włoskiego odrodzenia. Najbardziej spośród nich znane to metafora kochanka jako żołnierza (militat omnis amat ${ }^{58}$ ) oraz miłości jako wojny (militiae species amor est $\left.{ }^{59}\right)$.

Kenneth Burke wskazuje na uderzającą paralelność retoryki obecnej w Księciu i Sztuce kochania Owidiusza. Oba dzieła mają formę poradnika skutecznej egzekucji zdobywczych zamiarów. Pomimo że pierwsze doradza, jak zdobyć i utrzymać władzę, drugie zaś - jak zdobyć i utrzymać przy sobie kochankę, oba zajmują się swoistym „porzą dkiem potencji” i wskazują, jak tę potencję egzekwować czy wprowadzać $\mathrm{w}^{\mathrm{czyn}}{ }^{60}$. Ars bellica i ars amatoria łączy ta sama egzekucyjna retoryka, która za każdym razem odsyła do argumentu pozasłownego: siły zbrojnej w wypadku sztuki wojny czy zmysłowego oręża w wypadku sztuki miłości. Dzięki ekwiwalencji figur żołnierza i kochanka zdobycie kobiety znajduje swój retoryczny analogon w szarży wojskowej czy akcie przejęcia władzy. Nietrudno jednak zauważyć, że owe sensotwórcze operacje są skuteczne wyłącznie dlatego, że Sztuka kochania pisana jest z perspektywy męskiego libido dominandi. Owidiuszowa topika zrównująca atak miłosny z militarnym, dobrze Machiavellemu znana, wpleciona zostaje w retoryczny styl jego wywodów. To dlatego bojowa dyspozycja republikańskiego Rzymu, której pochwałę znajdujemy na każdej nieomal stronie Rozważań, może być przez autora referowana zarówno w poetyce Wenus, jak i Marsa: podbić, wkroczyć, posiąść. Poetyka ta zdradza swoje zmysłowe ugruntowanie w ityfallicznej dominacji seksualnej, a jej przeciwieństwem jest uznanie tego, co kobiece, za bierny przedmiot podboju i zaboru. Penetracja znajduje paralelę w inwazji i tym samym językiem oddać można zarówno gwałt na kobiecie, jak

58 Owidiusz Pieśni miłosne, w: Rzymska elegia miłosna, przeł. A. Świderkówna, Ossolineum i De Agostini, Wrocław 2005, s. 110. 
i gwałt na kraju, o czym świadczy opis Italii nękanej przez najeźdźcze armie, który znajdujemy w ostatnim rozdziale Księcia.

Wedle badaczki Owidiusza rzymska koncepcja męskiej seksualności zbudowana jest na „dystynkcji pomiędzy aktywnym penetrującym a pasywnym penetrowanym. Prawdziwi mężczyźni nie są penetrowani w odróżnieniu od «kobiet», których udziałem jest «cierpieć rzeczy kobiece», jak elokwentnie głosi znana fraza muliebria pati" ${ }^{\text {"1 }}$. O męskim jako niepenetrowalnym sugestywnie opowiada historia Kajnis/Kajnusa, którą znajdujemy w dwunastej księdze Metamorfoz Owidiusza. Kajnis, gwałtem wzięta przez Posejdona, błaga swego oprawcę, by ten wynagrodził jej cierpienie i zamienił ją w mężczyznę. Bóg spełnia prośbę ofiary i Kajnis przeobraża się w mężnego Kajnusa, który zostaje naczelnikiem ludu Lapitów. Co ciekawe, Posejdon, pojąwszy związek między niepenetrowalnością seksualną a militarnym opancerzeniem, sprawia, że Kajnusa nie imają się strzały. W ten sposób zostaje on uodporniony na wszelkie ataki. Jednak w rzymskiej elegii miłosnej męskości zagraża podatność na penetrację. Podstawowy emotikon, jaki jej zawdzięczamy, to strzała przebijająca serce. Wizerunek dzisiaj uznawany za esencję kiczu u elegistów obrazował dramatyczną sytuację żołnierza/kochanka, który utraciwszy swe opancerzenie, bezradnie przyjmuje miłosny cios, będący analogią penetracji. Odsłonięty i narażony na zranienie kochanek wydaje się „cierpieć rzeczy kobiece”. To dlatego poezja elegijna reprezentuje świat alternatywny wobec androcentrycznej virtus romana.

Powiada Owidiusz: „Mars często bywa zmienny i zdradna Wenera: / Zwyciężony wróg powstał, zwycięzca padł nieraz"62. Skoro miłość jest jak wojna, to możliwe są w niej, tak jak na wojnie, odwrócenia natarcia i obrony, zwycięstwa i kapitulacji. Dzieła poety twórczo eksplorują przemiany ról w miłosnych zmaganiach - z aktywnej na bierną i z dominującej na podporządkowaną. W ten sposób otwarta zostaje możliwość inwersji rodzaju. Role, pozycje i zachowania, tradycyjnie odmawiane kobiecie w męskich dziedzinach militariów i polityki, tutaj są dla niej dozwolone, a nawet stają się domeną jej mocy. W obszarze Wenery może ona nie być branką i sama stać się zdobywczynią. I na odwrót, rezygnacja z roli dominatora i oddanie się w miłosną niewolę, servitium amoris, pozwalają mężczyźnie doświadczyć tego, co kobiece. Z psychologiczną subtelnością elegiści studiowali niepokojący

61 A. Sharrock Gender and Sexuality, w: The Cambridge Companion to OVID, ed. by Ph. Hardie, Cambridge University Press, Cambridge 2006, s. 97.

62 Owidiusz Pieśni miłosne, s. 111. 
aspekt męskiego pragnienia bycia służebnikiem, niewolnikiem, ofiarą czy jeńcem dominy. Świadectwem tego libido dominantis jest formuła kapitulacji, która wychodzi z ust żołnierza-kochanka w Amores: „W więzy oddaję dłonie i w niewolę idę"63.

Motyw Marsa pokonanego przez Wenus jest obecny w literaturze renesansowej w różnych odmianach. Na przykład w piątym rozdziale poematu Africa Petrarki czytamy o nagłej miłości, jaką numidyjski król Masynissa zapałał do Sofonisby, żony pokonanego wroga. Pragnąc oddać wzajemną przechodniość zwycięstwa i porażki, Petrarka operuje ciągiem przestawień: oto „zwyciężona królowa mogła okiełznać dumnego zwycięzcę", tak iż Masynissa

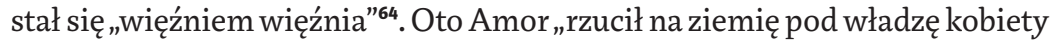
serce króla, niezwyciężonego w tylu sławnych bitwach"65. Oto „niepokonany na wojnie stał się niewolnikiem młodej kobiety"66. Aby oddać dramat batalii toczącej się we wnętrzu Masynissy, zaciekłej psychomachii między rozumem a "miękkimi” częściami jego duszy, poeta odwraca androcentryczny sens poetyki „twardości” i „rozkazu”. Tym razem służy ona nie opisowi dawania odporu namiętności, ale bycia przez nią pojmanym: „Twarde prawo miłości, rozkazując, ciągnęło go jakby związanego mocnymi łańcuchami" ${ }^{\text {"7 }}$.

Ars amatoria rozumiana jako seksualny podbój zakłada zarówno erotyzację aktywnej zdolności do brania w posiadanie, jak i biernej dyspozycji do oddawania $\operatorname{się}^{68}$. Ponieważ zerotyzowane są oba człony związku dominacji, odpowiadające im dwa przeciwstawne rodzaje libido mogą ulec odwróceniu i przemieszczeniu. Ekspresyjnie pokazuje to scena z poematu Lukrecjusza. Oto Marsa po miłosnym natarciu nęka „odwieczna rana miłości”, dlatego opadłszy z sił, „szuka spocznienia” na łonie kochanki' ${ }^{69}$. Jego zależność od Wenus staje się tak bezgraniczna, że adresując swe słowa do bogini, poeta powiada: „A gdy tak leży, ust jego tchnienie od twego zawisło"70. Pod wpływem

63 Tamże, s. 94.

64 F. Petrarka Africa, w: tegoż Wybór pism, przeł. M. Faleński, J. Kurek, K. Morawski, Zakład Narodowy im. Ossolińskich, Wrocław 1982, s. 117.

65 Tamże, s. 119.

66 Tamże, s. 124.

67 Tamże, s. 121.

Por. P. Bourdieu Męska dominacja, przeł. L. Kopciewicz, Oficyna Naukowa, Warszawa 2004, s. 31.

Lukrecjusz O naturze rzeczy, s. 54.

Tamże, s. 54 . 
kobiecej mocy wenerycznej męski bóg wojny porzuca „twarde żołnierskie mozoły” i odtąd nieuzbrojony zapada w „senny bezwład spokoju" "'1. Erotyczna gra przemiany, w wyniku której aktywna męskość i pasywna żeńskość zamieniają się miejscami, toczy się także na znanym obrazie Botticellego zatytułowanym Wenusi Mars. Widzimy tam, jak masculinum pod wpływem Wenus traci swą orężność i popada w zniewieściającą androgynię. Dźwięki hipnotycznej muzyki, sączone z muszli na rozkaz bogini, doprowadzają srogiego Marsa do utraty zmysłów. Pogrążony w błogim śnie pozostaje całkiem bezbronny, pozbawiony wojennego rynsztunku, z porzuconą bronią, którą zabawiają się dokazujące wokół fauny. Intrygująca jest postać siedzącej obok Wenus, niekwestionowanej dominatorki, która z chłodną badawczością przygląda się postępującej demaskulinizacji kochanka.

Odzyskanie twardej, rzymskiej cnoty, swoiście przez Machiavellego interpretowanej jako centaurialna męskość, miało być sposobem na przezwyciężenie zniewieściałego imposybilizmu, który trapił jego czasy.

Fortuna okazuje się bowiem najpotężniejsza tam, gdzie ludziom brakuje cnót - pisał - a ponieważ jest ona zmienna, często zmieniają się granice królestw i republik. Będzie tak zawsze dopóki nie pojawi się człowiek, który tak ukocha starożytność, że potrafi okiełznać fortunę i nie pozwoli jej dowodzić nam swej mocy po każdym wschodzie słońca. ${ }^{72}$

W korespondencji prywatnej odsłania zgoła inne oblicze. W liście do przyjaciela, florenckiego ambasadora w Rzymie, wyznaje:

Porzuciłem przeto myśli o wszystkich rzeczach wielkich i poważnych, nie sprawia mi już więcej żadnej przyjemności czytanie historii antycznych ani też zastanawianie się nad problemami współczesności; wszystko to zastąpione zostało przez biesiady o wiele słodsze, za które dzięki składam Wenus i Cyprydzie w obu postaciach. ${ }^{73}$

Niestrudzony laudator męskiej virtù traci smak zarówno dla starożytności, jak i bieżącej polityki. Zamiast tego znajduje przyjemność w dobrowolnym

71 Tamże.

N. Machiavelli Rozważania..., s. 486.

N. Machiavelli Listy prywatne, w: tegoż Wybór pism, s. 1092. 
zapadaniu się w sieć „utkaną przez Wenus"74. Nie tylko nie przeciwstawia się pętającym go więzom miłosnej niewoli, ale sam je dodatkowo wzmacnia: „udało mi się przekształcić jej delikatne nici w silne sploty, z węzłami tak umiejętnie zadzierzgniętymi, że rozplątać ich już się nie uda"75. Czyż nie wyraża tu przemożnej chęci, by samemu być effeminato? Czyż nie zaświadcza o tym, co wyjawiała już Owidiuszowa erotyka, że jednym z pragnień męskości jest libido dominantis?

$\mathrm{Na}$ obrazie Botticellego zatytułowanym Ujarzmienie centaura znajdujemy alegorię triumfu cnoty nad przywarami. Personifkacją cnoty jest Atena, przywary zaś uosabia teriantropiczna postać człowieka-konia. Atena, uderzająco podobna do wizerunków Wenus lub Flory z innych obrazów artysty, ciągnie za grzywę spokorniałego centaura. Alegorię triumfu cnoty reprezentuje także późniejsze dzieło, które wyszło spod pędzla Andrei Mantegny, znane jako Atena przepędzająca przywary z ogrodu cnoty. Na obrazie widnieją dwie rywalizujące ze sobą boginie: Atena zwyczajowo symbolizuje cnotę, Wenus zaś króluje wśród przywar. Wbrew zawartemu w tytule dzieła dydaktycznemu przesłaniu Wenera przedstawiona jest tu zaskakująco władczo: w triumfalnej i wyzywającej pozie niczym woltyżerka stoi na grzbiecie centaura.

W pisarstwie Machiavellego masculinum skonstruowane zostało w opozycji do tego, co żeńskie, a zarazem nobilitowało w męskości to, co bestialne. Jednak nieustająca męska potencja i sprawczość, a zarazem męska autonomia i autarkia, nie są do urzeczywistnienia. Znalazłszy się w zagrodzie Wenus, zdobywczy samiec przeobraża się w miłośnie zranioną kobietę albo inaczej nieujarzmialny centaur zamienia się w jedno ze zwierząt potulnie łaszących się u stóp dominatrix. 


\section{Abstract}

\section{Nina Gładziuk}

UNIVERSITY OF WARSAW

The Centaur in Venus's Barn: The Manly Desires of Machiavelli

While Machiavelli is usually viewed as the founder of sober political realism, consumed by concerns of acquiring and maintaining power, his thought is also notably masculine, replete with themes concerning male sex and gender. He condemns all manifestations of effeminacy and proclaims what could be called a centaurial ideal of masculinity. Gładziuk argues, however, that contained in Machiavelli's concept of the masculinum is a male desire to be unmanly.

\section{Keywords}

Machiavelli, masculinism, effeminacy, centaur, Circe, Venus, male desire to be unmanly 